\title{
ORGANIZATIONAL CULTURE IN THE ISLAMIC BOARDING SCHOOL : PHENOMENOLOGY REVIEW
}

\author{
Ahmad Musaddad \\ Islamic Educational Management Department, Sekolah Tinggi Agama Islam Cendekia Insani, \\ Situbondo, East Java, Indonesia \\ Email : ahmadmusaddad@staici.ac.id \\ DOI: http:// doi.org/10.33650/al-tanzim.v5i1.1982 \\ \begin{tabular}{l|l|l} 
Received: February 2021 & Accepted: March 2021 & Published: March 2021
\end{tabular}
}

\begin{abstract}
:
This research focuses on the facts and theories of organizational culture which include: 1) the formation of Salaf culture in modern Islamic boarding schools and 2) the maintenance of Salaf culture in the Modern Islamic boarding schools. This is a qualitative research with a phenomenological approach in the Salafiyah Syafi'iyah Islamic boarding school, Sukorejo, Situbondo. The results showed that organizational culture was formed by the founder's philosophy with the founder's education background and sourced from the salaf books known as four (4) elementary books. The maintenance of the organizational culture is manifested in the activities of the boarding school which include 1) Diniyah school obligations for all students; 2) Establishment of religious-based higher education institutions for mahasantri (Ma'had Aly organization); 3) Obligation to read the yellow book (kitab kuning) and the Koran properly for every student; 4) Obligation to pass basic Madrasah Diniyah; 5) Study of books at various places and times; 6) Wetonan, bandongan and Sorogan methods; 7) Method of muhafadloh or memorization; 8) curriculum system; and, 9) clothing and uniforms.
\end{abstract}

Keywords: Organizational Culture; Islamic Boarding School, Salaf

\begin{abstract}
Abstrak:
Penelitian ini mengambil fokus berdasarkan fakta dan teori budaya organisasi, yakni; 1) bagaimana pembentukan budaya Salaf di pondok pesantren modern?; dan, 2) bagaimana pemeliharaan budaya Salaf di pondok Pesantren Modern?. Penelitian ini menggunakan jenis penelitian kualitatif dengan pendekatan Fenomenologi di pondok pesantren Salafiyah Syafi'iyah Sukorejo Situbondo. Hasil penelitian menunjukkan bahwa; terbentuknya budaya organisasi di pondok pesantren Salafiyah Syaf'iyah Sukorejo Situbondo dibangun oleh filsafat pendiri yang dilatarbelakangi pendidikan pendiri dan bersumber dari kitab-kitab salaf yang dikenal dengan empat (4) kitab elementer. Pemeliharaan budaya organisasi yang dilakukan berupa kegiatan-kegiatan kepesantrenan, yakni yaitu 1) Wajib Sekolah Diniyah Bagi semua santri; 2) Mendirikan Lembaga Pendidikan Tinggi Berbasis Keagamaan bagi Mahasantri (Lembaga Ma'had Aly); 3) Wajib Mampu membaca Kitab kuning dan Al-Quran dengan baik bagi setiap calon lulusan di semua lembaga; 4) Santri Wajib lulus Madrasah Diniyah Dasar; 5) Kajian Kitab di berbagai tempat dan waktu; 6) Metode Wetonan, bandongan dan Sorogan; 7) Metode Muhafadloh atau hafalan; 8) Sistem kurikulum; dan, 9) Pakaian dan seragam.
\end{abstract}

Kata Kunci: Budaya Organisasi, Pondok Pesantren, Salaf 


\section{INTRODUCTION}

The term pesantren (Islamic Boarding School) is more popularly known as pondok pesantren. Pondok comes from the Arabic language fundaq which means hotel, dormitory, house, and simple residence (Yamadi, 2002).

Culturally, Islamic boarding school was born from Indonesian culture (Fitriyah, Wahid, \& Muali, 2018; Dakir \& Anwar, 2019). Pesantren historically contained not only Islamic meaning but also Indonesian authenticity. Pesantren institutions has emerged since Hindu-Buddhist era and Islam continued, preserved and Islamised it (Yamadi, 2002).

Streenbrink (1983) in his thesis proposed a different opinion. He concluded that pesantren originated from India and the system used in pesantren was a system that had been used by Javanese Hinduism in its teaching system. However, after Islam spread in Indonesia the system was adapted by the pesantren. On the other hand, the existence of pesantren in Java and in Indonesia generally developed along with the development of Hinduism; this did not precede the existence of Hindu.

Islamic boarding schools as communities and as educational institutions are large in number and widely spread across the country. They have played a major role in shaping religious Indonesians (Baharun \& Adhimah, 2019). This institution has created many leaders of Indonesiain the past, present and presumably also in the future. Pesantren graduates have actively participated in nation building (Mutohar, 2013).

Substantively, Islam does not carry out a dichotomy between religious knowledge and general science. However, this assumption continues to develop and becomes an assumption construction that is actually carried out by the Muslims themselves in their practical order. General sciences were marginalized and religious sciences were prioritized (Noorhayati, 2001). This phenomenon makes pesantren experience challenges in its ability to accommodate religious (non-formal) and general (formal) education institutions (Yunus, Mukhtar, \& Nugroho, 2019). In the end, slowly some pesantren began to transform from the salaf label to modern Islamic boarding schools.

Azra (2002) also stated that since the modernization and changes of Islamic education were intensified in various regions of the Muslim world, several traditional Islamic educational institutions have been eroded and displaced, unable to survive the expansion of the secular education system. In the end, several pesantren took the initiative to transform from a salaf system into a modern pesantren system that adopted the content and methodology of general education.

With the inclusion of formal education in pesantren, the culture of formal education culture adapted from the national culture must be accepted by the pesantren. On the other hand, pesantren with classical culture and salaf must also be preserved so that the characteristics of pesantren as Islamic educational institutions and Taffaquh Fiddin are not uprooted from their historical roots.

Modernization of pesantren in its development has slightly eroded the main objective of the establishment of the pesantren, i.e the reproduction of ulama (Syuhud, 2019). The modernization of pesantren develops and expands 
the function of the pesantren which was originally only a reproduction of ulama and taffaquhfiddin to become wider in order to answer the demands of the times. As a result, there are some pesantren that are unable to control their management and have lost their characteristics as pesantren that teach the values and study of the yellow book, and are instead dominated by their general education rather than religion (Muntholib, Maisah, \& Maryani, 2018).

According to Dhafier (1994), an important reform that occurred in pesantren occurred in 1910 with Denanyar pesantren in Jombang opened classes for women. In the 1920s the Tebuireng, Jombang and Singosari pesantren in Malang began teaching general subjects such as Indonesian, arithmetic, geography, history and the classical system in the pesantren began to appear. Furthermore, in the early 20th century, Gontor pioneered the establishment of a pesantren which emphasized the cadre aspects of Islamic education and open management. In this pesantren, students are equipped with the basics of religious knowledge and various life skills so that when they graduate, they can become entrepreneurs and foster society. Teaching methods were also been modernized.The opening of the madrasa system in pesantren since the 20th century was one of the characteristics of the disappearance of wandering santri and the application of the classical system changed the view of the santri towards dependence on formal diplomas as a result of their learning. Despite changes performed by pesantren, the numbers were limited compared to general schools. According to Dhafier, there are two reasons why pesantrenwere slow to make changes (Adhimiy, 2019). First, the kyai still maintain the basic objectives of pesantren education: to spread and defend Islam. Second, there were no experts according to the required needs. Changes in this system may be what makes pesantren survive in the midst of society even although there alos other factors such as (1) alternatives for prospective students and students who fail to enter PSB into public schools or UMPTN/PMB, (2) the tradition of populist Islamic boarding schools - not elitist- as valuable assets for the development of humanist pesantren education, (3) the efficacy of pesantren as cultural and religious strongholds for the younger generation, and (4) strong ties and intimacy with the surrounding community.

Dhofier (1994) emphasized that an institution or an organization is called a pesantren if it has several elements and elements that cannot be separated, including: dormitories, mosques, students, ustadz, kyai and the teaching of the ancient book. He classified the pesantren into two forms, the Salaf Islamic Boarding School and the Khalaf (Modern) Islamic Boarding School. However, in both Salaf and Khalaf Islamic boarding schools, teaching and study of the yellow book remains a focus that should prioritize the sticky learning model in the style of the pesantren including sorogan, bandongan and wetonan. This method, as stated by Sulthon Masyud and Khusnuuridlo in their book "Management of Islamic Boarding Schools" is unique, which is different from the modern methods.

The previous elaboration becomed the consideration for the author to conduct this research and is carried out with the theme "Organizational Culture in Islamic Boarding Schools: Phenomenology Studies at Salafiyah Syafi'iyah 
Sukorejo Situbondo Islamic Boarding Schools". The inclusion of formal and modern education systems into Islamic boarding schools does not always provide positive impact on the development and existence of pesantren. On the other hand, pesantren are required to carry out formal education to accommodate community needs for formal education as well as religious education. The researchers took the theme of organizational culture because according to Sharma (2017) that organizational culture is highly influential on the performance satisfaction of organizational members. The satisfaction will motivate members to behave in accordance with the direction of the organization through the vision. The theory of the function and influence of organizational culture is also strengthened by (Shahzad, 2012) in the results of his research which found that organizational culture washighly influential on improving organizational performance, especially if Islamic boarding schools or organizations have a very strong culture. In addition, organizational culture also functions to provide identity to its members which will differentiate between one member of the organization and other organizations, this is reinforced by research results Bingöl, Şener, \& Çevik, (2013) that organizational culture provided an identity that will strengthen the behavior of its members.

Another function of organizational culture based on Nikpour (2017) is to build commitment of organizational members in carrying out performance based on the values that have been built. Thus, it is very important to study and understand the organizational culture of pesantren through various researches.

This research was conducted at the Salafiyah Syafi'iyah Sukorejo Islamic boarding school, Situbondo, which is one of the major Islamic boarding schools in East Java. This pesantren was chosen as the object of research because at first this pesantren refused formal education system to become part of the boarding school education system. His caretaker, KHR. As'ad Syamsul Arifin did not approve of the formal education system because he was worried that the characteristics of the salaf pesantren that used the four Elementary books (Sullam Taufiq, Sullam Safinah, Ta'limul Muta'allim and Bidayatul Hidayah) as identity of salaf would shift and disappear with formal schools. In fact, he gave an ultimatum to his successors that it would be better for the pesantren to be eliminated than sinking the four elementary books as the reference for pesantren. Today, however, the pesantren continues to transform into a modern Islamic boarding school with an educational system; structure; and modern management. Even in 2017, this pesantren was successful in seeking to change the status of its university from the Ibrahimy Islamic Institute to become Ibrahimy University. Even so, this pesantren still exists to create generation of santri Ulama and Fiqh Expert (Fuqaha') according to the vision of this pesantren.

\section{RESEARCH METHODS}

In this study, a descriptive qualitative approach was used. Qualitative approach is a method for exploring and understanding the meaning that some individuals or groups of people think come from social or humanitarian problems (Creswell, 2009). This qualitative research process involves important efforts such as asking a number of questions and procedures, collecting specific data from participants, inductively analyzing data starting from common 
themes, and interpreting the meaning of the data.

The descriptive research method is a research method that has the aim of describing in full and in-depth social reality and various phenomena that occur in the community that is the subject of research so that the characteristics, charactersand models of the phenomena that occur are clearly described (Sanjaya, 2014). In this study, a qualitative phenomenological strategy was used.

Phenomenology strategy is a research strategy in which the researcher identifies the nature of human experience about a particular phenomenon (Creswell, 2009). In this process, the researcher puts aside his personal experiences in order to understand the experiences of the participants under study. The phenomenon that is described or fully described in this study is the organizational culture at the Salafiyah Syafi'iyah Sukorejo Islamic Boarding School, Situbondo.

\section{RESULTS AND DISCUSSION \\ Establishment of an Organizational Culture of the Salafiyah Syafi'iyah Sukorejo Situbondo Islamic Boarding School}

The formation of organizational culture that the researchers examined in this study is the formation of salaf culture that is closely related to the characteristics of early pesantren which were formed and projected as Taffaquh Fiddin and the creation of scholars. Masyhud and Khusnuuriddlo stated that pesantren is unique. This can be seen from several learning methods in several Islamic boarding schools such as the sorogan, wetonan, and bandongan methods. These three methods, which are a legacy of salaf ulama, are starting to disappear in some pesantren, especially modern pesantren. This shift in the culture of salaf education was influenced by the thoughts of Islamic boarding school researchers who later applied the concept of thought to the Kyai. A pesantren observer, Chumaedy argues that the pesantren education system must continue to develop and innovate following new and modern methodologies so that pesantren education can compete with other educational institutions.

Uniqueness expressed by Azra (2002) is that classical or salaf pesantren education is not framed by formalism which imposes certain time limits. Salaf and classical Islamic boarding schools provide freedom in learning. Students can come to madrasah or i, and they can also go directly to the teacher or Kyai to recite the Koran and study.

The formation of the salaf culture in the Salafiyah Syafi'iyah Sukorejo Situbondo Islamic boarding school as in general an organization is derived from the founder's philosophy, KHR. Syamsul Arifin and KHR. As'ad Syamsul Arifin. This is in accordance with the theory proposed by Robbins \& Schein (2001) that the formation of organizational culture is influenced and initiated by the founder of the organization. This theory is then strengthened by the results of research Rijal (2010) that leadership has a strong influence on the existence of an organizational culture that is formed. Therefore, the style and background of the leader will determine the type of culture that will characterize an organization, including pesantren. 
The salaf culture formed by the founders was based on the salaf ulama culture passed down through the Sanad route or the chain of history from teacher to student and so on. Through data mining, the authors found that the salaf culture in Salafiyah Syafi'iyah, Sukorejo Islamic boarding school originated from the founders, while the caregivers and the generations after them played more roles in maintaining the salaf cultures built by the founders. Through interaction between organizational members or individuals at the Sukorejo Islamic Boarding School, it focuses more on selecting subjects for book study at Madrasahs and general recitation in several places. Another source of organizational members is only on the side of building a modern organizational culture, such as the classical madrasah initiated by Syekh Dhofir Munawwar. This system was initially rejected by Kyai As'ad but based on the logical explanation from Syekh Dhofir Munawwar, this was later accepted and became part of the Madrasah Salafiyah Syafi'iyah Sukorejo Islamic boarding school system.

The salaf cultures at the Sukorejo Islamic boarding school which were formed by the founder were oriented towards the reproduction of the ulama. Therefore, the founder obliged all students to consistently study the yellow book as the basis of the students' mindset and behavior. The founder stipulated four elementary books that must be studied and must become a reference book for the thought and behavior of students. Even the founder gave an ultimatum that it is better for Islamic boarding schools to be eliminated if these four elementary books are ignored and not taught. The four books include Sullam Taufiq, Sullam Safinah, Ta'limul Muta'allim and Bidayatul Hidayah. The books referred to in outline contain about believe, Morals and law. The values of the four elementary books are designed to become the identity of the students that the students must hold firmly.

Thus, the values formed by the founder of Salafiyah Sukorejo pesantren are the values enshrined in the four books. One of the books set the moral values and the way of learning in Islam in the tradition of Salafus Salih scholars. Until later, students with broad vision and morals are formed. The study of this book is a mandatory reference.

As stated by Dhofier (1994), pesantren has elements that cannot be separated from each other including dormitories, students, mosques, teachers, kiai and the study of the yellow book. Therefore, the yellow book must still be studied as the identity of the pesantren with any typology as in the Sukorejo pesantren. In addition to being elements of the pesantren, the yellow book studies are also a tradition formed by the founder to become a spirit which is consistently carried out. The study of the yellow book must be the characteristic and superiority of pesantren as Islamic educational institutions in the midst of exposure to educational modernization.

Thus, the salaf cultures that have been formed by the founder of the Salafiyah Syafi'iyah Sukorejo Islamic boarding school, Situbondo aim to form Ulama, Wali Allah and Fuqaha based on the values of the four elementary books. As a pesantren organizational culture, they will greatly influence the effectiveness and efficiency of the pesantren's vision. Robbins' organizational 
culture function theory states that organizational culture can guide and control the behavior and attitudes of organizational members. Another function, according to Robbins, is that organizational culture will become an identity and differentiator between one organization and another (Robbins, 2001).

\section{Maintenance of Organizational Culture in Salfiyah Syafi'iyah Sukorejo Situbondo Islamic Boarding School}

The maintenance of the salaf culture in the Sukorejo Islamic boarding school is carried out consistently and continuously. The most decisive thing in maintaining a salaf culture is that the leader within the scope of the pesantren is the Kiai.

Currently the leadership of the Sukorejo Islamic Boarding School is the fourth generation. Each generation has different efforts and programs to maintain the salaf cultures formed by the founders. Therefore, to maintain the salaf culture, there are several programs and regulations designed with the intention of directing the behavior of students so that they stick to the salaf culture.

As proposed by Robbins on the theory of organizational culture maintenance, culture maintenance starts from the process of selecting candidate members of the organization, then the role of top management and socialization. The Salafiyah Syafi'iyah Sukorejo Islamic boarding school, Situbondo, cannot be separated from the theoretical stages described by Robbins. Horrison and Carrol have similar opinion that three forces play a very important part in maintaining a culture including selection practices, top management actions, and socialization methods. Recruitment of organizational members with the same vision and views as the salaf culture built by the Sukorejo Islamic boarding school began with a leadership influence and the big name of the founder known as Wali Allah. This has become an assumption and a separate value in society that the words (dawuh) are considered true and contain spiritual values. The power of this influence will make it easier for prospective members of the organization to submit to and obey the cultures that have been built in the pesantren organization. This is contained in the Ta'limul Muta'allim book about the concept of how to have morals to teachers or Kiai. If a student is not obedient to the teacher then his knowledge is believed to be of no benefit or blessing. However, compliance is within certain limits and not absolute.

Recruitment of organizational members with the same vision and views as the salaf culture built by the Sukorejo Islamic boarding school began with a leadership influence and the big name of the founder known as Wali Allah. This has become an assumption and a separate value in society that the words (dawuh) are considered true and contain spiritual values.

The top managementin the context of pesantren is caregiver or Kiai. At the Sukorejo Islamic boarding school, Situbondo, the role of top management in maintaining the salaf culture is to set an example through behavior. It also designs students programs and activities whose aim is to maintain the salaf cultures created by the founders. From the results of data mining, the researchers found several programs designed by caregivers in maintaining salaf 
cultures. However, these findings are adjusted for the focus of research on education. The following is how to maintain the tradition of the salaf education concept:

1. Mandatory of Diniyah School For all students

This regulation comes from the founders that in an effort to mobilize students to continue to study the yellow book which has been integrated into institutions, students are obliged to go to Madrasah Diniyah school which is held in the morning. In fact, to reinforce this rule, the founder gave fatal sanctions for students who did not go to Diniyah school for up to three days without hindrance by being dismissed from the boarding school;

2. Establishing Religious-Based Higher Education Institutions for Mahasantri (Ma'had Aly Institution)

The Ma'had Aly Institute is a higher education institution founded by KHR. As'adSyamsul Arifin as a form of maintenance of the yellow book studies which are concentrated for the Fiqh subject. This institution was also established to recruit scholars who are ready to serve in the community. This institution is required only for students who wish to study fiqh. Even so, educational institutions that focus on the study of yellow books are primarily very influential on the maintenance of the salaf culture in the Sukorejo Islamic boarding school;

3. The obligation to be able to read the yellow book and the Koran properly for every prospective graduate in all institutions

This rule was emphasized by the third Kyai, KHR. Fawaid As'ad Syamsul Arifin. He stated that every prospective student from all levels of educational institutions must pass the book reading test and read the Koran well. This is to maintain its distinctive characteristic as a pesantren by displaying the skills to read the yellow book and the Al-Quran;

4. Obligations to pass Madrasah Diniyah Dasar

The fourth-generation caregiver, KHR. Ahmad AzaimIbrahimy made a policy to further strengthen the salaf culture in the form of the religious ability of students through the study of the yellow book. This was made so that students who factually emphasized formal schooling were still equipped with the ability to master the yellow book well after graduation. Such efforts are also strengthened administratively through a letter of agreement with the santri guardian when new students are admitted. The content of the agreement is that students are required to pass Diniyah Dasar, and as a consequence if they do not pass, the recommendation letter as alumni and formal school diplomas will be suspended by the pesantren until the students graduate from Madrasah Diniyah;

5. The study of the Books (Kitab) at any places and times

In addition to several studies on the yellow book that have been integrated in the Diniyah school, book studies are also carried out in various places such as in each student's room, mosque, caretaker room etc. While this book study is not mandatory, these studies to preserve the sustainability of the yellow book study in order to exist are reviewed and 
studied in the Sukorejo Islamic boarding school;

6. Wetonan, bandongan dan Sorogan Method

The learning method and study of the yellow book at the Salafiyah Syafi'iyah Sukorejo Islamic boarding school still maintains the salaf methods that have been applied previously in the form of Wetonan, Bandongan and Sorogan methods. Wetonan and Bandongan methods are used in Madrasah and general recitation can be done in several places. Meanwhile, sorogan method is used privately to some ustadz and mahasantri Ma'had Aly. This pesantren tried several modern methods which were designed with a certain concept for several years but in the end it returned to the three salaf methods.

7. Muhafadlohor memorization method.

This method is the most important method in the salaf education system. In the Sukorejo pesantren, this method is still maintained and is almost applied at all levels including Ma'had Aly.

8. Curriculum System

The curriculum system used at the Sukorejo Islamic Boarding is classical curriculum system at Madrasah Diniyah. The subjects in the form of the yellow book were selected by several ustadz, school principals or caregivers without using syllabus references. This is only based on the experience of the cleric or caregiver when they were still studying at another boarding school.

9. Uniforms and clothing

The typical appearance of the santri (student), such as wearing a kopyah, white cap, moslem outfit and sarongstill represents the activitiesof the students. Santri are strictly prohibited from removing the kopyah or cap in the pesantren environment and even returning home. This is a culture that the founder instilled deeply. This provision also applies to guests who will enter the pesantren area.

The above efforts are the role and existence of top management in maintaining salaf cultures. This is also performed so that the vision of the founder who wants his students to become scholars, Wali Allah and Fuqoha' is achieved. In addition, this prevented the Sukorejo Islamic boarding school from losing its identity and characteristic of being an Islamic boarding school that was still able to produce cadres who could read, study and apply the yellow book.

The last stage of the process of maintaining organizational culture is socialization. The socialization stages carried out by the pesantren began with the development of information about cultures at the Sukorejo Islamic boarding school through printed media in the form of calendars and brochures; online media on the pesantren website and information from the story of the santri guardian and alumni. In robbins theory, this is known as theprearrival stage, i.e a period of cultural learning before entering the organization. Islamic boarding school history books and biographies of the founders or leaders are given and orientation of the students through directions from the caregivers or senior santri. This stage is called the encounter stage,i.e the period of knowing the salaf 
culture desired by the pesantren. The final stage is the metamorphosis stage, where new members or students have adapted to the salaf culture of the Sukorejo Islamic boarding school.

\section{CONCLUSION}

Thesalaf culture in Salafiyah Syafi'iyah Sukorejo Islamic boarding school originates from the philosophy of the founder as a scholar and is known as a guardian of Allah. The position of the ulama as well as Wali Allah is closely related to his philosophy in building a culture of the pesantren organization which was established in the context of reproducing ulama, guardians of Allah and Fuqoqa'. Therefore, the basis used in building the organizational culture of the pesantren is the books of the salaf ulama which are then designed into four elementary books of Sullam Taufiq, Sullam Safinah, Ta'limul Muta'allim and Bidayatul Hidayah. The books referred to in outline contain about akidah, morals and law. The values of the four elementary books are designed to become the identity of the students that the students must hold firmly. The caregivers and leaders afterwards in addition to contributing to building a culture of salaf in choosing recommended books.

Preservation of salaf culture is carried out by the leaders and the successors of the Kiai. This is performed in stages according to Robbins' theory of the maintenance of organizational culture from selection, the role of top management/Kiai and outreach. Several activities and programs as a form of support for the resilience of the salaf culture include 1) Diniyah school obligations for all santri; 2) Establishing Religious-based Higher Education Institutions for Mahasantri (Ma'had Aly Institutions); 3) The obligation to be able to read the yellow book and the Koran properly for every prospective graduate in all institutions; 4) Obligation to pass Madrasah Diniyah Dasar; 5) Study of the Books at various places and times; 6) Wetonan, bandongan and Sorogan methods; 7) Muhafadloh or memorization method; 8) curriculum system; and, 9) Clothing and uniforms.

\section{REFERENCES}

Adhimiy, S. (2019). Learning Innovation in Pesantren: The Strategy of Stifin Method for Enhancing Children's Intelligence Potential. TARBIYA: Journal of Education in Muslim Society, 6(2), 233-250. https://doi.org/10.15408/tjems.v6i2.9247

Azra, Azyumardi. 2002. Paradigma Baru Pendidikan Nasional: Rekontruksi dan Demokratisasi. Jakarta: Kompas.

Baharun, H., \& Adhimah, S. (2019). Adversity Quotient: Complementary Intelligence in Establishing Mental Endurance Santri in Pesantren. Jurnal Ilmiah Islam Futura, 19(1), 128-143. 
Bingöl, D., Şener, İ., \& Çevik, E. (2013). The Effect of Organizational Culture on Organizational Image and Identity: Evidence from a Pharmaceutical Company. Procedia-Social and Behavioral Sciences, 99, 222-229. https://doi.org/10.1016/j.sbspro.2013.10.489.

Creswell, J. W. (2009). Research Desaign (Qualitative, Quantitative, and Mixed Aproaches). California: SAGE Publications.

Dakir, \& Anwar, H. (2019). Nilai-Nilai Pendidikan Pesantren sebagai Core Value; dalam Menjaga Moderasi Islam di Indonesia. Jurnal Islam Nusantara, 3(2), 495-517.

Dhofier, Zamakhsari. (1994). Tradisi Pesantren: Studi tentang Pandangan Hidup Kyai. Jakarta: LP3ES.

Fitriyah, W., Wahid, A. H., \& Muali, C. (2018). Eksistensi Pesantren dalam Pembentukan Kepribadian Santri. Jurnal Studi Keislaman Dan Ilmu Pendidikan, Vol.(No. 2), 1-19.

Muntholib, Maisah, \& Maryani. (2018). Management of Pesantren in Development of Islamic Religion Education in Jambi Province. International Journal of Reserach Granthaalayah, 6(1), 407-420. https://doi.org/10.5281/zenodo.1451886

Muthohar, A., \& Anam, N. (2013). Manifesto Pendidikan Islam dan Pesantren. Yogyakarta: Pustaka Pelajar.

Nikpour, A. (2017). The Impact of Organizational Culture on Organizational Performance: The Mediating Role of Employee's Organizational Commitment. International Journal of Organizational Leadership, 6, 65-72.

Rijal, S. (2010). Leadership Style and Organizational Culture in Learning Organization: A Comparative Study. International Journal of Management \& Information Systems (IJMIS), 14(5), 119-128.

Robbins, S. P. (2001). Organizational Behavior. New Jersey: Prentice-Hall, Inc.

Robbins, S. P., \& Judge, T. A. (2013). Organizational Behavior. New Jersey: Pearson Education.

Sanjaya, Wina. (2014). Penelitian Pendidikan Jenis, Metode dan Prosedur. Jakarta: Prenada Media Group.

Shahzad, Fakhar. (2012). Impact of Organizational Culture on Organizational Performance: An Overview. Interdisciplinary Journal of Contemporary Research in Business, 3(3), 975-985.

Sharma, Pooja. (2017). Organizational Culture as a Predictor of Job Satisfaction: The Role of Age and Gender. Management, 22(1), 35-48.

Steenbrink. (1983). Pesantren Madrasah Sekolah. Jakarta: LP3ES.

Syuhud, S. (2019). Partisipasi dalam Pengambilan Keputusan Strategis di Pondok Pesantren. Al-Tanzim: Jurnal Manajemen Pendidikan Islam, 3(2), 3748. https://doi.org/10.33650/al-tanzim.v3i2.658

Yamadi. (2002). Modernisasi Pesantren: Kritik Nur Cholis Majid terhadap Pendidikan Islam Tradisional. Jakarta: Ciputat Press

Yunus, Y., Mukhtar, J., \& Nugroho, I. (2019). Manajemen Pengembangan Pondok Pesantren (Studi Kasus di Pondok Pesantren As'adiyah Belawa Baru, Masamba, Sulawesi Selatan). Al-Tanzim: Jurnal Manajemen Pendidikan Islam, 3(1), 82-101. 